\title{
Estrogen Receptor- $\alpha$, Sexual Dimorphism and Reduced-Size Liver Ischemia and Reperfusion Injury in Mice
}

\author{
HIROHISA HARADA, SULAIMAN BHARWANI, KEVIN P. PAVLICK, KENNETH S. KORACH, AND \\ MATTHEW B. GRISHAM \\ Departments of Molecular and Cellular Physiology (H.H., K.P.P., M.B.G.) and Pediatrics LSU Health Sciences \\ Center (S.B.), Shreveport, Louisiana 71130, U.S.A.; and Laboratory of Reproductive and Developmental \\ Toxicology, National Institutes of Health (K.S.K.), Research Triangle Park, North Carolina 27709, U.S.A.
}

\begin{tabular}{|c|c|}
\hline \multicolumn{2}{|c|}{ ABSTRACT } \\
\hline $\begin{array}{l}\text { Estrogen }\left(\mathrm{E}_{2}\right) \text { exerts its effect on target organs principally by } \\
\text { interacting with specific estrogen receptors (ER) such as ER- } \alpha \text { or } \\
\text { ER- } \beta \text {. The role that these } \mathrm{E}_{2} \text { receptors play in mediating the } \\
\text { protective effects observed in RSL }+\mathrm{I} / \mathrm{R} \text { induced injury remains } \\
\text { to be defined. To study the role of ER- } \alpha \text {, we anesthetized female } \\
\text { and male wild type (wt; C57Bl/6) and ER- } \alpha \text {-deficient ( } \alpha \text { ERKO) } \\
\text { mice and subjected them to } 70 \% \text { liver ischemia for } 45 \text { min } \\
\text { followed by resection of the remaining } 30 \% \text { nonischemic lobes } \\
\text { and reperfusion of the ischemic tissue. For some experiments, wt } \\
\text { and } \alpha \text { ERKO male mice were injected with } \mathrm{E}_{2} \text {. Survival was } \\
\text { monitored on a daily basis while liver injury was assessed by } \\
\text { quantifying serum alanine aminotransferase (ALT) levels and } \\
\text { histopathology. Hepatic eNOS mRNA levels were evaluated } \\
\text { using semi-quantitative RT-PCR. Our data showed that untreated } \\
\text { females or males treated with } \mathrm{E}_{2} \text { survived RSL }+\mathrm{I} / \mathrm{R} \text { surgery } \\
\text { indefinitely whereas all male mice given vehicle died within } 3-5 \\
\text { days following surgery. This protective effect was diminished in } \\
\alpha \text { ERKO female mice such that only } 40 \% \text { of } \alpha \text { ERKO females } \\
\text { survived } 7 \mathrm{~d} \text { following RSL }+\mathrm{I} / \mathrm{R} \text {. Furthermore, liver injury was }\end{array}$ & $\begin{array}{l}\text { significantly higher in } \alpha \text { ERKO females compared with their wt } \\
\text { counterparts and similar to those seen in wild type males and } \\
\alpha \text { ERKO males. The protective effect observed in wild type } \\
\text { females or } \mathrm{E}_{2} \text { treated males correlated well with increases in } \\
\text { hepatic eNOS message whereas both male and female } \alpha \text { ERKO } \\
\text { mice exhibited significantly lower levels of eNOS mRNA. We } \\
\text { conclude that this protection may in part be due to the } \mathrm{E}_{2} / \mathrm{ER}- \\
\alpha \text {-mediated activation of eNOS. (Pediatr Res 55: } \mathbf{4 5 0}-\mathbf{4 5 6} \text {, } \\
\text { 2004) } \\
\text { Abbreviations } \\
\text { NO, nitric oxide } \\
\text { ROS, reactive oxygen species } \\
\text { eNOS, endothelial nitric oxide synthase } \\
\boldsymbol{\alpha E R K O , ~ e s t r o g e n ~ r e c e p t o r ~ a l p h a ~ k n o c k o u t ~} \\
\text { I/R, ischemia/reperfusion } \\
\text { wt, wild type } \\
\text { RSL+I/R, reduced-size liver with ischemia and reperfusion } \\
\text { injury }\end{array}$ \\
\hline
\end{tabular}

Hepatic resection with concomitant periods of ischemia and reperfusion $(\mathrm{I} / \mathrm{R})$ is a common occurrence in certain surgical procedures such as split liver or living donor transplantation (1, 2). These types of transplantations represent surgical alternatives to whole liver transplantation and are being applied to expand the depleted donor organ pool $(1,2)$ as well as provide children with size-matched livers. Indeed, the high death rate $(7 \%$ to $15 \%)$ in pediatric liver patients waiting for sizematched cadaveric liver donors (3) has led to the utilization of these types of innovative surgical techniques such as living related transplants (LRT), the reduced size (cut-down) liver

Received June 26, 2003; accepted September 5, 2003.

Correspondence: Sulaiman Bharwani, MD, Department of Pediatrics, LSU Health Sciences Center, 1501 King's Hwy, Med School bldg. \#4-315, Shreveport, LA 711303932, U.S.A.; e-mail: sbharw@1suhsc.edu

Some of this work was supported by grants from the NIH (DK47663 and DK43875).

DOI: 10.1203/01.PDR.0000110524.88784.DD grafts and split grafts. These technical advances have led to the reduction in the waiting list mortality (4), however, the success has been fraught with difficulties, medical as well as ethical. For example, the hepatocellular injury induced by $\mathrm{I} / \mathrm{R}$ is known to impair liver regeneration and may lead to primary graft dysfunction and failure $(2,5,6)$. The mechanisms by which $\mathrm{RSL}+\mathrm{I} / \mathrm{R}$ promotes liver injury are not clear at the present time. However, numerous experimental studies using warm, full-size liver $\mathrm{I} / \mathrm{R}$ indicate that certain pro-inflammatory cytokines (e.g. TNF- $\alpha$, IL-1 $\beta$, IL-12), reactive oxygen species and neutrophils may contribute to hepatocellular injury $(7,8)$. Recent work by Selzner and coworkers has shown that I/R impairs the regenerative capacity of the liver, although a protective strategy was not identified or proposed (5).

It is well appreciated that sexual dimorphism exists in susceptibility to and mortality from a variety of vascular diseases including vascular occlusive disease, stroke, and ath- 
erosclerosis (9). Furthermore, retrospective clinical studies suggest that donor and/or recipient gender may influence the outcome of liver transplantation, however these data are variable and no clear consensus has been reached $(10,11)$.

Using a mouse model of RSL $+\mathrm{I} / \mathrm{R}$ to mimic RSL transplantation, we found that $100 \%$ of female mice survived indefinitely following surgery, whereas all male mice died within $5 \mathrm{~d}$ following RSL $+\mathrm{I} / \mathrm{R}$ (1). This protective effect in females correlated well with reduced liver injury compared with their male counterparts as assessed by lower serum alanine aminotransferase (ALT) levels in females versus males at $20 \mathrm{~h}$ following RSL $+\mathrm{I} / \mathrm{R}$. To address the mechanisms by which female mice are protected from the injurious effects of $R S L+I / R$, female mice were ovariectomized, allowed to recover for $14 \mathrm{~d}$, and then subjected to RSL + IR. We found that the 7-d survival of ovariectomized female mice was reduced to $14 \%$ versus $100 \%$ for sham-operated mice (1). This protective effect in females appeared to be due to ovarian $17 \beta$-estradiol $\left(\mathrm{E}_{2}\right)$ as administration of the selective $E_{2}$ receptor antagonist ICI 182,780 decreased the 7-d survival of female mice following $\mathrm{RSL}+\mathrm{I} / \mathrm{R}$ from $100 \%$ to $13 \%$ compared with their vehicletreated counterparts. In addition, male mice treated with exogenous $E_{2}$ significantly improved their survival from $0 \%$ in vehicle treated to $87 \%$ in $\mathrm{E}_{2}$ treated mice (1). The protective effect of $E_{2}$ treatment on male mice agreed well with serum ALT as shown by the significant reduction compared with their vehicle controls. On the other hand, the ALT levels were significantly elevated by ICI 182,780 administration to intact female mice compared with the vehicle-treated controls. Histologic inspection revealed that $\mathrm{E}_{2}$ administration to males attenuated hepatocellular injury and female mice administered ICI 182,780 had enhanced histopathological injury similar to that of untreated male mice.

The mechanisms by which endogenous or exogenous $E_{2}$ protects the liver from the injurious effects of $\mathrm{RSL}+\mathrm{I} / \mathrm{R}$ have not been identified however this hormone is known to have dramatic effects on the expression and activity of the endothelial cell isoform of nitric oxide synthase (eNOS). Estrogen is known to rapidly stimulate eNOS to synthesize NO via a nongenomic yet estrogenreceptor- $\alpha$ (ER- $\alpha$ ) and $\mathrm{Ca}^{++}$ dependent manner (12-14). Several studies have demonstrated the presence of plasmalemmal caveolae-associated ER- $\alpha$, which binds estrogen and mediates $\mathrm{Ca}^{++}$uptake and "activation" of eNOS via serine/threonine kinase Akt-activation and involved the translocation of eNOS from the plasma membrane to perinuclear region in the cytosol $(14,15)$. In addition, estrogen is known to transcriptionally activate the expression of eNOS in endothelial cells via the more classical genomic mechanisms (16-19). We have recently demonstrated that hepatic eNOS plays an important role in limiting $\mathrm{I} / \mathrm{R}$ induced liver injury in vivo in model of full size liver $\mathrm{I} / \mathrm{R}$ injury as well as $\mathrm{RSL}+\mathrm{I} / \mathrm{R}$. We hypothesized that estrogen-dependent protection in our model of RSL $+\mathrm{I} / \mathrm{R}$ may be due to enhanced expression of hepatic eNOS $(1,2)$. Because there appears to be a predominance of ER- $\alpha$ in the liver (20) and because the role that ER- $\alpha$ plays in mediating the protective effect of estrogen in $\mathrm{RSL}+\mathrm{I} / \mathrm{R}$ induced injury is unknown, we wished to examine the role of ER- $\alpha$ in protecting female mice or $E_{2}$-treated male mice subjected to $\mathrm{RSL}+\mathrm{I} / \mathrm{R}$.

\section{METHODS}

Animals. 8-10 wk-old (16-23 g) male and female C57Bl/6 wild type mice or mice genetically deficient in ER- $\alpha$ ( $\alpha$ ERKO) were used for these studies. $\alpha$ ERKO mice were generated by targeted disruption of the ER- $\alpha$ gene via the insertion of a neomycin cassette into the first coding exon of this steroid receptor as previously described (21). These animals are devoid of full-length $\mathrm{ER} \alpha(\mathrm{ER} \alpha 66)$. All experimental procedures were in compliance with the Guide for the Care and Use of Laboratory Animals, with Federal and State regulations and in accordance with the Council of the American Physiologic Society.

Reduced size liver ischemia reperfusion. Mice were fasted for 16-18 h overnight. Before the experiment they were anesthetized with a single intramuscular injection (i.m.) of ketamine $(150 \mathrm{mg} / \mathrm{kg})$ and xylazine $(7.5 \mathrm{mg} / \mathrm{kg})$ and a midline laparotomy was performed. The intestinal loops were gently exteriorized to expose the liver and the portal vein in the abdominal cavity. The lobes were identified and cleared of the surrounding membranes and ligaments. To achieve $70 \%$ of liver ischemia the hepatic arterial and portal venous blood supply to the left lateral and median lobes was clamped using a microaneurysm clip. Bypass portal flow through the nonischemic lobes (right lateral, quadrate and caudate lobes) prevented intestinal congestion. Then the mice were given an i.p. dose of heparin $(200 \mathrm{U} / \mathrm{kg})$ to prevent blood clotting during the ischemic time period. The abdominal wall was approximated, covered with gauze to prevent heat loss and placed under the warmer. The mice were left under warm lights. After $45 \mathrm{~min}$ of ischemia, the clip was removed to reperfuse the liver. Next the vessels supplying the nonischemic lobes were ligated with 6-0 chromic sutures. All the nonischemic lobes were excised immediately after tying their pedicles with $4-0$ silk sutures thus leaving the mice with a reperfused liver that has essentially been reduced to $30 \%$.

The abdominal cavity was closed and the mice were returned to their cages with access to regular food and water. Sham control animals, although treated in an identical fashion, received neither hepatectomy nor vascular clamping. Postsurgery the mice were observed on a daily basis for survival study until day 7 after which they were euthanized if they had survived until then. In the time-course study, serum and tissues were collected at different time points and analyzed upon sacrificing the animals. For some experiments, animals were treated with $17 \beta$-Estradiol $\sim 1 \mu \mathrm{g} /$ dose in $100 \mu \mathrm{L}$ of corn oil with $0.1 \%$ ethanol $(40 \mathrm{ng} / \mathrm{g}$ body weight s.c. $24 \mathrm{~h}$ before surgery) followed by a second dose administered at the time of reperfusion providing a total dose of $80 \mathrm{ng} / \mathrm{g}$ body weight.

Tissue and blood analyses. Serum was collected at various times following surgery to quantify alanine aminotransferase (ALT). Liver specimens were removed, weighed and stored in $10 \%$ PBS-buffered formalin for histopathologic assessment or snap-frozen in liquid nitrogen and stored at $-70^{\circ} \mathrm{C}$ for mRNA extraction for RT-PCR studies. Commercially available re- 
agents (from Sigma Chemical Co., St. Louis, MO, U.S.A.) were used to measure ALT.

Histologic analysis. JB-4 plastic was used to embed the formalin fixed liver tissues. $5-\mu \mathrm{m}$ sections were stained with hematoxylin/eosin. Liver specimens obtained at $20 \mathrm{~h}$ post $\mathrm{RSL}+\mathrm{I} / \mathrm{R}$ underwent histologic scoring using a modification of the scoring system described by Clavien and coworkers (22). Liver injury was quantified using Grade 0 for no or minimal evidence of injury, Grade 1 for mild injury with cytoplasmic vacuolation and focal nuclear pyknosis to grade 5 with severe hemorrhage in the tissues, total disruption of parenchyma with lymphocyte and neutrophil infiltrates.

Endothelial cell NOS mRNA expression. Semiquantitative RT-PCR was performed one hour post surgery to determine eNOS mRNA. Trizol reagent (GIBCO/BRL) was used to isolate total RNA from the liver tissue. Using MuLV Reverse Transcriptase (Applied Biosystems, Foster City, CA, U.S.A.) one microgram of RNA was reverse transcribed to cDNA which was then amplified by the primers for the mouse eNOS gene: sense, 5'-GCAGAAGAGTCCAGCGAACA-3' and antisense, 5'-GGCAGCCAAACACCAAAGTC -3'. A total of 30 thermal cycles were used each thermal cycle being $94^{\circ} \mathrm{C}$ for $30 \mathrm{~s}, 58^{\circ} \mathrm{C}$ for $30 \mathrm{~s}$, and $72^{\circ} \mathrm{C}$ for $30 \mathrm{~s}$. After the final cycle incubation at $72^{\circ} \mathrm{C}$ was done for $5 \mathrm{~min}$. The same cDNA reaction was used to do the PCR amplification of the housekeeping gene (GAPDH). Alpha Innotech gel documentation system (San Leandro, CA, U.S.A.) was used to do the densitometric analysis of RT-PCR products, which were also stained by ethidium bromide for visual analysis. The ratio of eNOS and GAPDH band intensity helped document eNOS mRNA expression, which was subsequently presented as relative values to controls.

\section{RESULTS}

Wt male and female mice subjected to $R S L+I / R$. As previously reported $(1,2)$, we found that all wild type (untreated) females survived RSL $+\mathrm{I} / \mathrm{R}$ surgery indefinitely whereas all wild type male mice injected with vehicle died within 3-5 d following surgery (Fig. 1).

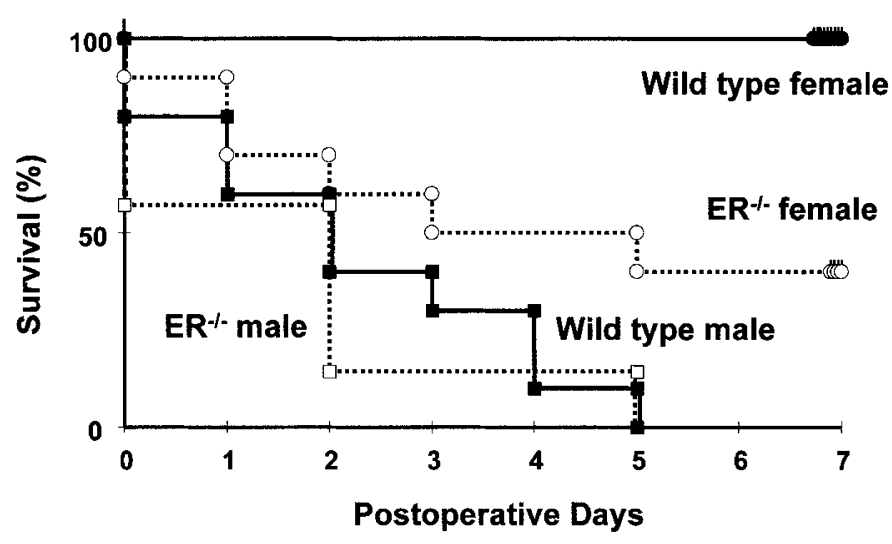

Figure 1. Effects of ER- $\alpha$ deficiency on the survival of male and female mice subjected to RSL $+\mathrm{I} / \mathrm{R}$. Survival rates were $100 \%$ for wild type females and $0 \%$ for wild type males. Marked reduction in 7 -d survival $(40 \%, p<0.05)$ was observed in $\alpha$ ERKO female mice compared with their wild type controls. $\alpha$ ERKO male and female mice subjected to $R S L+I / R$. The protective effect was diminished in $\alpha$ ERKO female mice such that only $40 \%$ of $\alpha$ ERKO females survived $7 \mathrm{~d}$ following $\mathrm{RSL}+\mathrm{I} / \mathrm{R}$ (Fig. 1). We also observed that greater than $80 \%$ of the $\alpha$ ERKO male mice died within $2 \mathrm{~d}$ compared with $60 \%$ mortality we observed with wt males (Fig. 1).

Elevated serum ALT levels with hepatic injury in a ERKO female mice. The increased mortality in the $\alpha$ ERKO female mice correlated well with liver injury as assessed by serum ALT levels. We observed significantly higher serum ALT levels in $\alpha$ ERKO female mice compared with their wt counterparts (Fig. 2). We also observed that wild type and $\alpha$ ERKO male mice exhibited similar degrees of serum ALT elevation (Fig. 2).

$\alpha$ ERKO female mice have severe histopathological evidence of injury. The quantitative indices of liver injury were largely confirmed by histopathological inspection (Fig. 3). Extensive nuclear pyknosis with necrosis, disintegration of hepatic cords and focal hemorrhages were observed in wild type males and $\alpha$ ERKO males and females. Wild type females in contrast showed preservation of hepatic architecture with minimal focal nuclear pyknosis or no injury.

$E_{2}$ treatment increases hepatic eNOS message and improves survival in male mice. Because $\mathrm{E}_{2}$ may promote both $\mathrm{ER} \alpha$-dependent and -independent physiologic responses, we treated both wt and $\alpha$ ERKO male mice with exogenous $\mathrm{E}_{2}$. We found that $\mathrm{E}_{2}$ enhanced the 7-d survival of wt male mice from $0 \%$ to $90 \%$ (Fig. 4). Surprisingly, we found that $E_{2}$ treatment also enhanced survival of $\alpha$ ERKO males from $0 \%$ to $60 \%$ (Fig. 4). The protective effect observed in wt females or $E_{2}$ treated wt males appeared to correlate well with increases in hepatic eNOS message (Fig. 5).

\section{DISCUSSION}

The recent developments of novel surgical techniques such as living related transplants (LRT), the reduced size and split liver grafts as well as advancements in organ preservation methods has improved the outcome of RSL transplants for children making them comparable to those of whole liver

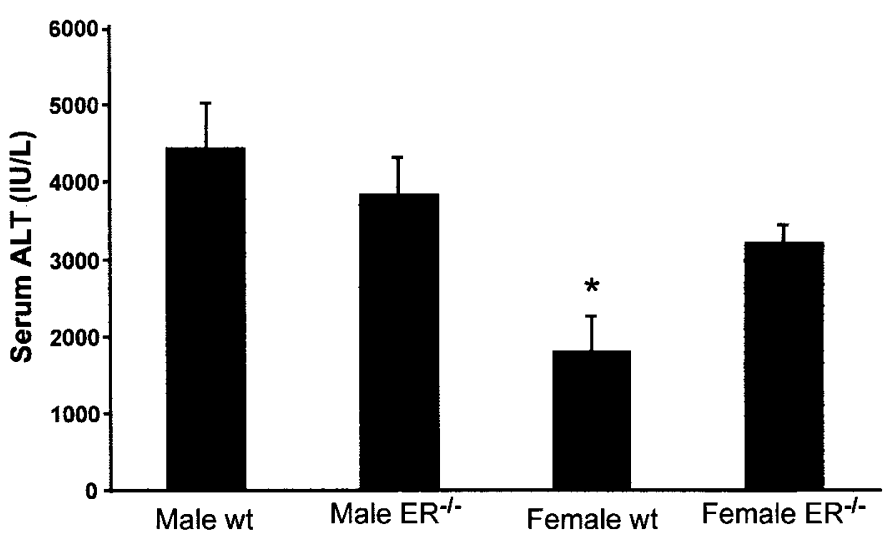

Figure 2. Serum alanine aminotransferase (ALT) levels at $20 \mathrm{~h}$ following $\mathrm{RSL}+\mathrm{I} / \mathrm{R}$. Although no significant difference was found between wt and $\alpha$ ERKO male mice, serum ALT was significantly elevated in $\alpha$ ERKO female mice compared with their wt controls $(p<0.05)$. 

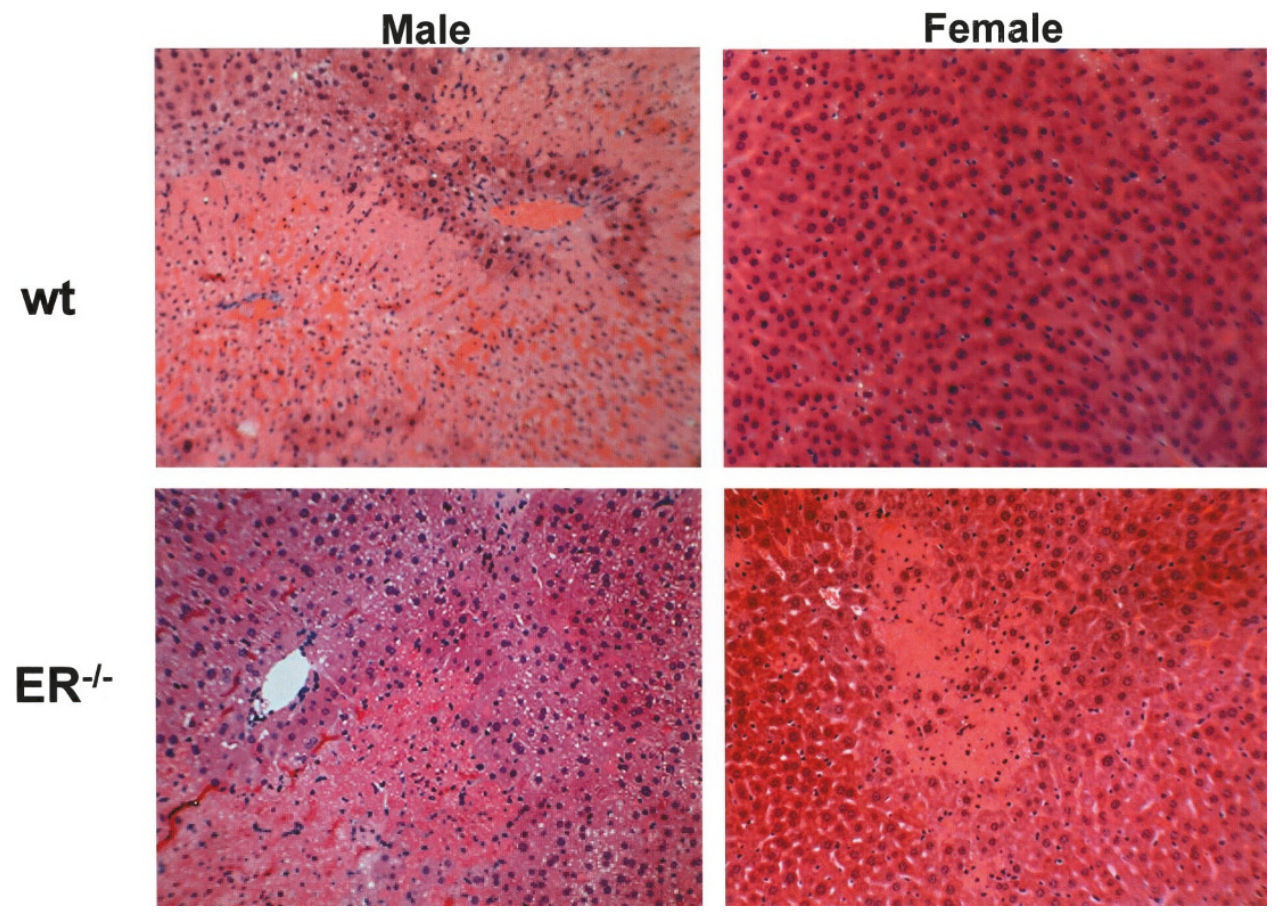

Figure 3. Liver histopathology $20 \mathrm{~h}$ following RSL $+\mathrm{I} / \mathrm{R}$. Marked necrosis with extensive nuclear pyknosis and disintegration of hepatic cords and focal hemorrhages were observed in both male wild type and aERKO mice as well as female $\alpha$ ERKO mice. Wild type female mice exhibited remarkable preservation of hepatic architecture.

transplants (23). However, the enthusiasm for the use of these types of surgical techniques has been tempered by a variety of problems to both donor and recipient. There are reports of increased risk of biliary complications that have been attributed to ischemic sensitivity of the left lateral segment of the liver among other factors (3). Donor factors also affect the outcome of liver transplant in adults as well as children. There will be an added challenge in older children and adolescents due to increase in pediatric as well as adult obesity and the prevalence of nonalcoholic steato-hepatitis. Hepatic resection in itself with concomitant ischemia and reperfusion injury plays a significant role in such surgeries $(6,23)$. The gender differences are now increasingly recognized in a variety of vascular conditions like atherosclerosis, stroke and shock $(9,24,25)$. A study in a large

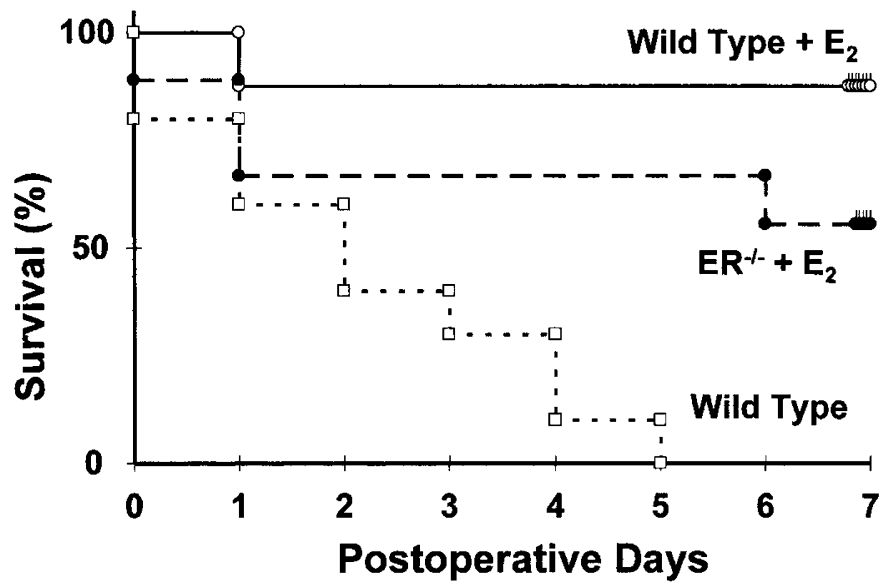

Figure 4. Effect of estrogensupplementation on 7-d survival of male mice following $\mathrm{RSL}+\mathrm{I} / \mathrm{R}$. cohort of whole liver transplants recipients showed significant improved patient survival in females compared with the males (10). There is no significant study in children looking at the difference in graft or patient survival in prepubertal versus postpubertal patients. A single center study of 355 children undergoing primary whole liver transplants did not show any gender difference in graft survival but the pre and post pubertal differences were not taken into account (11).

In a characterized mouse model we have recently demonstrated that untreated female mice or $\mathrm{E}_{2}$-treated male mice are protected from the injurious effects of $\mathrm{RSL}+\mathrm{I} / \mathrm{R}$ by an $\mathrm{E}_{2^{-}}$ dependent mechanism that requires the expression of hepatocellular eNOS $(1,2)$. Data obtained in these studies strongly suggested that the sexual dimorphism observed in this model of

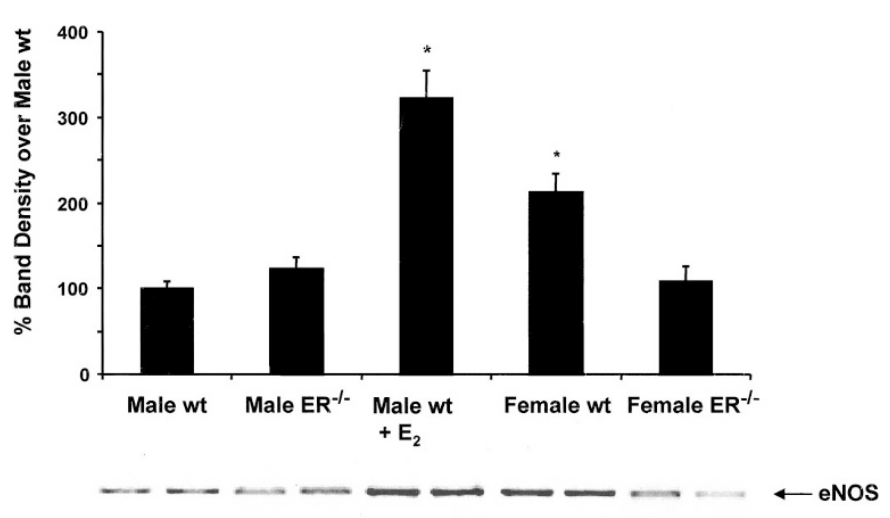

Figure 5. Hepatic eNOS message levels in male and female wt and $\alpha$ ERKO mice at $1 \mathrm{~h}$ following RSL $+\mathrm{I} / \mathrm{R}$. Note eNOS message from female wt and male wt $+\mathrm{E}_{2}$ (bars with*) significant when compared with wt male eNOS message. 
split liver transplantation was mediated by $\mathrm{E}_{2} / \mathrm{ER}$ interactions because treatment of female mice with the $\mathrm{E}_{2}$ antagonist ICI 182,780 decreased survival and increased liver injury following $\mathrm{RSL}+\mathrm{I} / \mathrm{R}$ (1). Because ER- $\alpha$ but not ER- $\beta$ is expressed principally in the rodent liver (20) we hypothesized that $E_{2} /$ ER- $\alpha$ protects the liver and improves survival of female mice or $\mathrm{E}_{2-}$ treated male mice. ER- $\alpha$ perform most of their functions via the constitutive activity of activation Function 1 (AF-1) domain located in the N-terminal region and some via AF-2 domain located in the $\mathrm{C}$-terminal region.

To test our hypothesis we used mice with targeted disruption of the ER- $\alpha$ (21). These animals are devoid of full-length ER $\alpha$ (ER $\alpha 66$, that harbors the ligand-independent transcriptional activation function AF-1) but do possess two ER- $\alpha$ mRNA spliced variants termed E1 and E2. The E1 transcript encodes for a chimeric ER- $\alpha$ protein in which amino acids 92-155 of the B domain of the wild type ER- $\alpha$ protein are replaced with 7 amino acids from a small portion of the neomycin insert. This eliminates or greatly diminishes AF-1 function but not DNA or ligand binding AF-2 transactivation function (26). Although this mutant isoform of ER- $\alpha$ does promote $\mathrm{E}_{2-}$ dependent transcriptional activity, it does so at a much lower activity compared with full length $\operatorname{ER} \alpha 66(26,27)$. Data obtained in the present study demonstrate that nonovariectomized $\alpha \mathrm{ERKO}$ female mice are more sensitive to injurious effects of RSL $+\mathrm{I} / \mathrm{R}$ than their wt counterparts such that survival decreased from $100 \%$ in wt mice to only $40 \%$ in the $\alpha$ ERKO mice (Fig. 1). Although survival of $\alpha$ ERKO male mice was not affected as dramatically as in females, we did observe a greater mortality of $\alpha$ ERKO male mice at $2 \mathrm{~d}$ following $\mathrm{RSL}+\mathrm{I} / \mathrm{R}$ than wt males (Fig. 1). The increased mortality in female $\alpha E R K O$ mice appeared to correlate with increased liver injury as assessed by serum ALT levels and histopathology (Figs. 2 and 3). Surprisingly, when $\alpha$ ERKO males were given exogenous $\mathrm{E}_{2}$, survival increased from $0 \%$ to $60 \%$ at $7 \mathrm{~d}$ following surgery (Fig. 4). At first glance, these data would suggest that at least some of the beneficial effects of endogenous or exogenous $E_{2}$ might be mediated by ER- $\alpha$ independent mechanisms. For example, it is possible that some of the protective effects may be mediated by $\mathrm{E}_{2} / \mathrm{ER}-\beta$ interactions. A direct interaction of $\mathrm{E}_{2}$ with hepatocellular ER- $\beta$ is less likely since this specific receptor is not found in the rodent liver (20). If ER- $\beta$ were involved in the protection observed in this model then one would have to assume that ER- $\beta$ located in other tissues may be mediating liver protection indirectly. Studies to directly assess the role of ER- $\beta$ are currently under investigation.

Another possibility for ER- $\alpha$ independent protective effects may be due to the well-known antioxidant/free radical scavenging properties of $E_{2}$. It is known for example that $E_{2}$ attenuates LDL oxidation and decreases superoxide and hydrogen peroxidation (28-31). Again, this possibility is unlikely since it would take supra-physiologic serum levels of $E_{2}$ to scavenge oxidants and free radicals in vivo. A more likely explanation for relatively modest reduction in survival of $\alpha$ ERKO female mice or the unexpected increase in survival of $\alpha$ ERKO male mice given exogenous $\mathrm{E}_{2}$ may relate to the presence of the E1 mRNA spliced variant. As mentioned above, this transcript encodes for a chimeric ER- $\alpha$ protein that lacks or has greatly reduced AF-1 function but retains the DNA or ligand binding domain and AF-2 transactivation function of wild type ER- $\alpha$ protein (32). Indeed, Pendaries et al. have demonstrated that the protein encoded by E1 is sufficient to drive the production of eNOS-derived NO (32). Based upon our previous work demonstrating that the $\mathrm{E}_{2}$-mediated protective effect in our model of RSL $+\mathrm{I} / \mathrm{R}$ is dependent upon the presence of eNOS, we would predict some protection in the $\alpha$ ERKO mice. Another interesting finding of the present work that may have important physiologic implications is the observation that although serum levels of estrogen are known to be 10 times higher in nonovariectomized $\alpha \mathrm{ERKO}$ versus wt female mice (33), these circulating levels of the $E_{2}$ are not apparently sufficient to fully protect female mice from the injurious effects of RSL $+\mathrm{I} / \mathrm{R}$. Thus, the partial survival observed in our nonovariectomized $\alpha$ ERKO females may be due to the presence of other isoforms of ER- $\alpha$ such as E1 still active in these knock out mice with high circulating estrogen levels resulting in residual AF-2 transactivation function (32). Since our $\alpha$ ERKO mice lack or have greatly diminished AF-1 function, we conclude that AF-1 transactivation may be important in the survival and hepatoprotective effects observed in female mice subjected to the surgery.

The precise mechanisms by which $\mathrm{E}_{2} / \mathrm{ER}-\alpha$ mediated increases in eNOS-derived NO protect the liver from RSL $+\mathrm{I} / \mathrm{R}$ are not completely understood. Estrogen stimulates eNOS to synthesize NO through a genomic or transcription dependent mechanism (16-19) as well as nongenomic yet ER- $\alpha$ and $\mathrm{Ca}^{++}$-dependent manner $(12-15,34)$. Estrogen binding to the plasmalemmal caveolae-associated ER- $\alpha$ causes $\mathrm{Ca}^{++}$uptake and activation of eNOS via serine/threonine kinase Aktactivation pathway leading to the translocation of eNOS from the plasma membrane to the perinuclear cytosolic region (1215). Recently Statins (3-hydroxy-3methylglutaryl (HMG) CoA reductase inhibitors) classically known to have cholesterol lowering effects have been shown to have eNOS activating effect (35-37) and in our recent study we have shown the hepatoprotective effect of Pravastatin with increase in eNOS activation in our model (2). We know for certain that although $\mathrm{E}_{2}$ and most probably ER- $\alpha$ are important for protection, eNOS activity is required since eNOS deficient female mice are not protected against the injurious effects of the surgery (2). How eNOS-derived NO protects the liver is the subject of current investigations. We do know, for example that NO promotes liver regeneration following partial hepatectomy by limiting the pro-apoptotic activity of TNF- $\alpha$ (38). Our own work with eNOS knock out mice suggests that NO may be crucial in limiting the neutrophil mediated hepatocellular injury $(1,2$, $39-42)$. NO is also known to inhibit ROS-mediated reactions and since $\mathrm{I} / \mathrm{R}$ increases ROS production $(7,43)$, the protective function of $\mathrm{NO}$ may be through ROS detoxification. Increased eNOS derived NO may be protective via cGMP-dependent vasodilatation and enhanced perfusion of the postischemic liver in our model.

As the most frequently prescribed medication in the United States (44), estrogen has received both widespread acclaim and most recently profound criticism while our understanding of the ever-expanding nonreproductive presence of estrogen 
makes it indispensable. With the rise of body mass index in North American children, the split graft may not be adequate for either the child or the adult and primary dysfunction, nonfunction and failure of the graft, may further rise. To minimize risks to the parents as donors for the living related transplants measures such as limiting the extent of resection and procuring smaller grafts are being recommended (45). The pediatric recipients in either case often inevitably run the risk of getting insufficient liver mass to work with and are often at the mercy of the liver's regenerative capability. Inadequate size increases the risk of complication and failure (46). Ischemia/ reperfusion injury is known to reduce the liver regenerative capacity (5) and is a cause of further insult. Estrogen is known to increase liver weight through receptor as well as nonreceptor mechanisms as evident in the experiments with double knockouts (44). In light of the adverse effects of estrogen supplements particularly long term, it is crucial to develop targeted receptor specific therapies if we were to use it for the purpose of enhancing graft and host survival in liver transplants. The approach may also address the increasing burden of obesity and fatty livers since estrogen is known to reduce fat.

We therefore propose that better regeneration of smaller grafts may be achieved through better preservation techniques and use of solutions that may include estrogen receptor agonists and/or HMG CoA reductase inhibitors such as statins (37), both classes being eNOS activators. We also propose that estrogen flush or eNOS activator flush at the time of harvest before in-vivo or ex-vivo splitting may improve the outcome of small for size liver transplants. Estrogen or ER agonists may prove beneficial in reducing fat (44) as well as cholesterol (47) and enhance the functional reserve of the regenerating graft and could be one of the strategies to address compromised quality of donor livers with the rise of obesity. The data appears to be particularly relevant to the adolescent and male liver donors and recipients.

\section{REFERENCES}

1. Harada H, Pavlick KP, Hines IN, Hoffman JM, Bharwani S, Gray L, Wolf RE, Grisham MB, 2001 Selected contribution Effects of gender on reduced-size liver ischemia and reperfusion injury. J Appl Physiol 91:2816-2822

2. Harada H, Pavlick KP, Hines IN, Lefer DJ, Hoffman JM, Bharwani S, Wolf RE, Grisham MB, 2003 Sexual dimorphism in reduced-size liver ischemia and reperfusion injury in mice: Role of endothelial cell nitric oxide synthase. Proc Natl Acad Sci 100:739-744

3. Sokal EM, Cleghorn G, Goulet O, Da Silvera TR, McDiarmid, Whitington P, 2002 Liver and intestinal transplantation in Children:Working Group Report of the First World Congress of Pediatric Gastroenterology, Hepatology, and Nutrition. J Pediatr Gastroenterol Nutr 35:S151-S158

4. De Ville de Goyet J, Hausleithner V, Reding, R, 1993 Impact of inno-vative techniques on the waiting list and results in pediatric liver transplantation. Transplantation 56:1130-1136

5. Selzner M, Camargo CA, Clavien PA 1999 Ischemia impairs liver regeneration after major tissue loss in rodents: protective effects of interleukin-6. Hepatology 30:469475

6. Strasberg SM, Lowell JA, Howard TK 1999 Reducing the shortage of donor livers: what would It take to reliably split livers for transplantation into two adult recipients? Liver Transpl Surg 5:437-450

7. Jaeschke H 1991 Reactive oxygen and ischemia/reperfusion injury of the liver. Chem Biol Interact 79(2):115-136

8. Lentsch AB, Kato A, Yoshidome H, McMasters KM, Edwards MJ, 2000 Inflammatory mechanisms and therapeutic strategies for warm hepatic ischemia/reperfusion injury. Hepatology 32:169-173

9. Hayward CS, Kelly RP, Collins P 2000 The roles of gender, the menopause and hormone replacement on cardiovascular function. Cardiovasc Res 46:28-49

10. Jain A, Reyes J, Kashyap R, Dodson SF, Demetris AJ, Ruppert K, Abu-Elmagd K, Marsh W, Madariaga J, Mazariegos G, Geller D, Bonham CA, Gayowski T, Cac- ciarelli T, Fontes P, Starzl TE, Fung JJ 2000 Long-term survival after liver transplantation in 4,000 consecutive patients at a single center. Ann Surg 232:490-500

11. Pillay P, Van Thiel DH, Gavaler JS, Starzl TE 1990 Donor gender does not affect liver transplantation outcome in children. Dig Dis Sci 35:686-689

12. Chen Z, Yuhanna IS, Galcheva-Gargova Z, Karas RH, Mendelsohn ME, Shaul PW 1999 Estrogen receptor alpha mediates the nongenomic activation of endothelial nitric oxide synthase by estrogen. J Clin Invest 103:401-406

13. Haynes MP, Sinha D, Russell KS, Collinge M, Fulton D, Morales-Ruiz M, Sessa WC, Bender JR 2000 Membrane estrogen receptor engagement activates endothelial nitric oxide synthase via the PI3-kinase-Akt pathway in human endothelial cells. Circ Res 87:677-682

14. Mendelsohn ME 2000 Nongenomic, ER-mediated activation of endothelial nitric oxide synthase: how does it work? What does it mean? Circ Res 87:956-960

15. Hisamoto K, Ohmichi M, Kurachi H, Hayakawa J, Kanda Y, Nishio Y, Adachi K, Tasaka K, Miyoshi E, Fujiwara N, Taniguchi N, Murata Y 2001 Estrogen induces the Akt-dependent activation of endothelial nitric- oxide synthase in vascular endothelial cells. J Biol Chem 276:3459-3467

16. Kleinert H, Wallerath T, Euchenhofer C, Ihrig-Biedert I, Li H, Forstermann U 1998 Estrogens increase transcription of the human endothelial NO synthase gene: analysis of the transcription factors involved. Hypertension 31:582-588

17. MacRitchie AN, Jun SS, Chen Z, German Z, Yuhanna IS, Sherman TS, Shaul PW 1997 Estrogen upregulates endothelial nitric oxide synthase gene expression in fetal pulmonary artery endothelium. Circ Res 81:355-362

18. Nuedling S, Kahlert S, Loebbert K, Doevendans PA, Meyer R, Vetter H, Grohe C 199917 Beta-estradiol stimulates expression of endothelial and inducible NO synthase in rat myocardium in-vitro and in-vivo. Cardiovasc Res 43:666-674

19. Sakamoto M, Uen T, Nakamura T, Hashimoto O, Sakata R, Kin M, Ogata R, Kawaguch T, Torimura T, Sata M 2001 Estrogen upregulates nitric oxide synthase expression in cultured rat hepatic sinusoidal endothelial cells. J Hepatol 34:858 -864

20. Pelletier G 2000 Localization of androgen and estrogen receptors in rat and primate tissues. Histo Histopathol 15(4):1261-1270

21. Lubahn DB, Moyer JS, Golding TS, Couse JF, Korach KS, Smithies O 1993 Alteration of reproductive function but not prenatal sexual development after insertional disruption of the mouse estrogen receptor gene. Proc Natl Acad Sci 90:1116211166

22. Camargo Jr., C A, Madden JF, Gao W, Selvan RS, Clavien PA 1997 Interleukin-6 protects liver against warm ischemia/reperfusion injury and promotes hepatocyte proliferation in the rodent. Hepatology 26:1513-1520

23. Keeffe EB 2001 Liver transplantation: current status and novel approaches to liver replacement. Gastroenterology 120:749-762

24. Dubey RK, Jackson EK 2001 Cardiovascular protective effects of 17beta-estradiol metabolites. J Appl Physiol 91:1868-1883

25. Mendelsohn ME, Karas RH 1999 The protective effects of estrogen on the cardiovascular system. N Engl J Med 340:1801-1811

26. Kos M, Denger S, Reid G, Korach KS, Gannon F 2002 Down but not out? A novel protein isoform of the estrogen receptor alpha is expressed in the estrogen receptor alpha knockout mouse. J Mol Endocrinol 29:281-286

27. Couse JF, Korach, KS 1999 Estrogen receptor Null Mice: What have we learned and where will they lead us? Endocr Rev 20(3):358-417

28. Arnal JF, Clamens S, Pechet C, Negre-Salvayre A, Allera C, Girolami JP, Salvayre R, Bayard F 1996 Ethinylestradiol does not enhance the expression of nitric oxide synthase in bovine endothelial cells but increases the release of bioactive nitric oxide by inhibiting superoxide anion production. Proc Natl Acad Sci 93:4108-4113

29. Buyon JP, Korchak HM, Rutherford LE, Ganguli M, Weissman G 1984 Female hormones reduce neutrophil responses in vitro. Arthritis Rheum 27:623-630

30. Maziere C, Auclair M, Ronveaux MF, Salmon S, Santus R, Maziere JC 1991 Estrogens inhibit copper and cell-mediated modification of low density lipoprotein. Atherosclerosis 89:175-182

31. Zuckerman SH, Bryan N 1996 Inhibition of LDL oxidation and myeloperoxidase dependent tyrosyl radical formation by the selective estrogen receptor modulator raloxifene. Atherosclerosis 126:65-75

32. Pendaries C, Darblade B, Rochaix P, Krust A, Chambon P, Korach KS, Bayard F, Arnal JF 2002 The AF-1 activation-function of ER alpha may be dispensable to mediate the effect of estradiol on endothelial NO production in mice Proc Natl Acad Sci 99:2205-2210

33. Couse JF, Curtis SW, Washburn TF, Lindzey J, Golding TS, Lubahn DB, Smithies O, Korach KS 1995 Analysis of transcription and estrogen insensitivity in the female mouse after targeted disruption of the estrogen receptor gene. Mol Endocrinol 9:1441-54

34. Rubanyi GM, Freay AD, Kauser K, Sukovich D, Burton G, Lubahn DB, Couse JF, Curtis SW, Korach KS 1997 Vascular estrogen receptors and endothelium-derived nitric oxide production in the mouse aorta. Gender difference and effect of estrogen receptor gene disruption. J Clin Invest 99:2429-2437

35. Davignon J, Laaksonen R 1999 Low-density lipoprotein-independent effects of statins. Curr Opin Lipidol 10:543-559

36. Laufs U, La, Fata V, Plutzky J, Liao JK 1998 Upregulation of endothelial nitric oxide synthase by HMG CoA reductase inhibitors. Circulation 97:1129-1135

37. Lefer AM, Scalia R, Lefer DJ, 2001 Vascular effects of HMG CoA-reductase inhibitors (statins) unrelated to cholesterol lowering: new concepts for cardiovascular disease. Cardiovasc Res 49:281-287

38. Rai RM, Lee FY, Rosen A, Yang SQ, Lin HZ, Koteish A, Liew FY, Zaragoza C, Lowenstein C, Diehl AM 1998 Impaired liver regeneration in inducible nitric oxide synthase deficient mice. Proc Natl Acad Sci 95:13829-13834

39. Hines IN, Hoffman JM, Scheerens H, Day BJ, Harada H, Pavlick KP, Bharwani S, Wolf R, Gao B, Flores S, McCord JM, Grisham MB 2002 Regulation of Post- 
Ischemic Liver Injury Following Different Durations of Ischemia. Am J Physio Gastrointest Liver Physiol 284:G536-G545

40. Hines IN, Kawachi S, Harada H, Pavlick KP, Hoffman JM, Bharwani S, Wolf RE, Grisham MB 2002 Role of nitric oxide in liver ischemia and reperfusion injury. Mo Cell Biochem234-235:229-237

41. Kawachi S, Hines IN, Laroux FS, Hoffman J, Bharwani S, Gray L, Leffer D, Grisham MB 2000 Nitric oxide synthase and postischemic liver injury. Biochem Biophys Res Commun 276:851-854

42. Laroux FS, Pavlick KP, Hines IN, Kawachi S, Harada H, Bharwani S, Hoffman JM, Grisham MB 2001 Role of nitric oxide in inflammation. Acta Physiol Scand 173:113118

43. Jaeschke H 1999 Kupffer cell-induced oxidant stress during hepatic ischemiareperfusion: does the controversy continue? Hepatology 30:1527-1528
44. Lindberg MK, Weihua Z, Andersson N, Moverare S, Gao H, Vidal O, Erlandsson M, Windahl S, Andersson G, Lubahn DB, Carlsten H, Dahlman-Wright K, Gustafsson JA, Ohlsson C 2002 Estrogen receptor specificity for the effects of estrogen in ovariectomized mice. J Endocrinol 174:167-178

45. Otte JB 2002 History of pediatric liver transplantation. Where are we coming from? Where do we stand? Pediatr Transplant 6:378-387

46. Kiuchi T, Kasahara M, Uryuhara K, Inomata Y, Uemoto S, Asonuma K, Egawa H, Fujita S, Hayashi M, Tanaka K 1999 Impact of graft size mismatching on graft prognosis in liver transplantation from living donors. Transplantation 67:321-327

47. Hodgin JB, Knowles JW, Kim, H-S, Smithies O, Maeda N 2002 Interaction between endothelial nitric oxide synthase and sex hormones in vascular protection in mice. J Clin Invest 109:541-548 